\title{
Aplikasi Metode Taguchi Untuk Menurunkan Tingkat Kecacatan Pada Produk Paving
}

\author{
Dian Anggraini*, Shanty Kusuma Dewi, Thomy Eko Saputro \\ Jurusan Teknik Industri, Fakultas Teknik, Universitas Muhammadiyah Malang \\ Jl. Raya Tlogomas 246 Malang \\ *Surel: anggraini.diaan@yahoo.com
}

\begin{abstract}
Home Industry Putih Jaya is a company engaged in the paving blocks manufacturing which in producing paving certainly wanst to minimize any product defects. Known types of paving product that often occured is an easily cracked paving. An effort in the first stage to reduce the level of disability in this company is to identify the factors that affect product quality paving using fishbone diagram followed by the Taguchi method which is to determine the most influential factor and improve product quality paving so the defect rate can be decreased. From the data calculation with the fishbone diagram, there are six factors that influential. Among the six factors, those will be identified factor has the greatest influence resulting product quality deviates toward standards quality. Conclusion of the results showed that percentage of defect that occurs in the company initially around 4\%, while by using the proposed improvement by Taguchi method decreases to $2 \%$. The decreasing of defect percentage of defect means that the improvement of product quality is successfully. The factors the most influential factors to the paving is a drying process with the largest value of percent contribution in the amount of $34.5 \%$.
\end{abstract}

Keywords : Quality Control, Fishbone Diagram, Taguchi Methods.

\begin{abstract}
Abstrak
Home Industry Putih Jaya merupakan perusahaan yang bergerak dibidang pembuatan paving blok yang ingin meminimasi adanya kecacatan produk dalam proses produksinya. Paving mudah retak merupakan jenis kecacatan yang sering terjadi. Tahapan pertama dalam usaha menurunkan tingkat kecacatan adalah dengan melakukan identifikasi faktor-faktor yang berpengaruh terhadap kualitas produk. Metode yang digunakan adalah fishbone diagram, kemudian dilanjutkan dengan Taguchi untuk mengetahui faktor yang paling berpengaruh dan meningkatkan kualitas produk sehingga tingkat kecacatan menurun. Dari hasil pengolahan data dengan fishbone diagram terdapat enam faktor yang berpengaruh. Diantara ke enam faktor tersebut dicari faktor dengan pengaruh terbesar yang mengakibatkan kualitas produk menyimpang terhadap standar kualitas. Dari hasil yang diperoleh dapat disimpulkan besarnya persentase kecacatan yang terjadi pada perusahaan awalnya berkisar 4\% sedangkan persentase hasil aplikasi dengan menggunakan metode Taguchi menurun menjadi 2\%. Penurunan persentase kecacatan berarti menyatakan adanya peningkatan kualitas produk. Adapun faktor yang paling mempengaruhi kualitas produk tersebut adalah waktu proses pengeringan dengan nilai persen kontribusi terbesar yaitu sebesar 34,5\%.
\end{abstract}

Kata Kunci : Pengendalian Kualitas, Fishbone Diagram, Metode Taguchi.

\section{Pendahuluan}

Industri kecil Putih Jaya merupakan industri rumahan yang memproduksi paving, genteng, dan gipsum. Dalam produksi paving tentunya bahan baku yang dibutuhkan haruslah sesuai dengan kualitas semestinya. Perusahaan ingin meningkatkan kualitas dan mengurangi kecacatan produk sehingga harus dilakukan 
pengerjaan ulang dari produk yang dihasilkan. Tetapi, perusahaan masih memiliki kerusakan produk dalam produksinya. Diketahui jenis kecacatan produk paving yang sering terjadi diantaranya adalah paving mudah retak. Dari data observasi diketahui bahwa tingkat kecacatan produk yang dihasilkan cukup tinggi, yaitu sebesar $3 \%$ sampai $5 \%$ per produksi per hari. Sedangkan toleransi kecacatan yang di berikan tidak lebih dari $2,5 \%$ per produksi per hari. Jika masalah kecacatan ini tidak dapat di atasi, maka dapat mempengaruhi kualitas produk yang dihasilkan.

Sesuai dengan permasalahan tersebut, perlu dilakukan upaya untuk mengidentifikasi faktor-faktor kontrol yang berpengaruh terhadap kualitas produk, terutama pada faktor proses (method) dan bahan baku (material). Tujuan makalah ini adalah memberikan metode penyelesaian untuk perusahaan dalam mendapatkan komposisi bahan baku yang tepat. Sehingga diperoleh paving yang memenuhi spesifikasi. Salah satu metode yang dapat digunakan untuk mengidentifikasi faktor-faktor yang mempengaruhi kualitas paving block dan menentukan komposisi yang tepat adalah dengan menggunakan desain eksperimen Taguchi.

\section{Metode Penelitian}

Pada poin ini akan dijelaskan tahapan sistematik dalam pemecahan masalah dan menentukan bagaimana sistem akan dibangun. Dengan adanya metodologi ini, maka tahapan pemecahan masalah dapat dilaksanakan secara terstruktur. Berikut ini tahapan penelitian yang dilakukan :

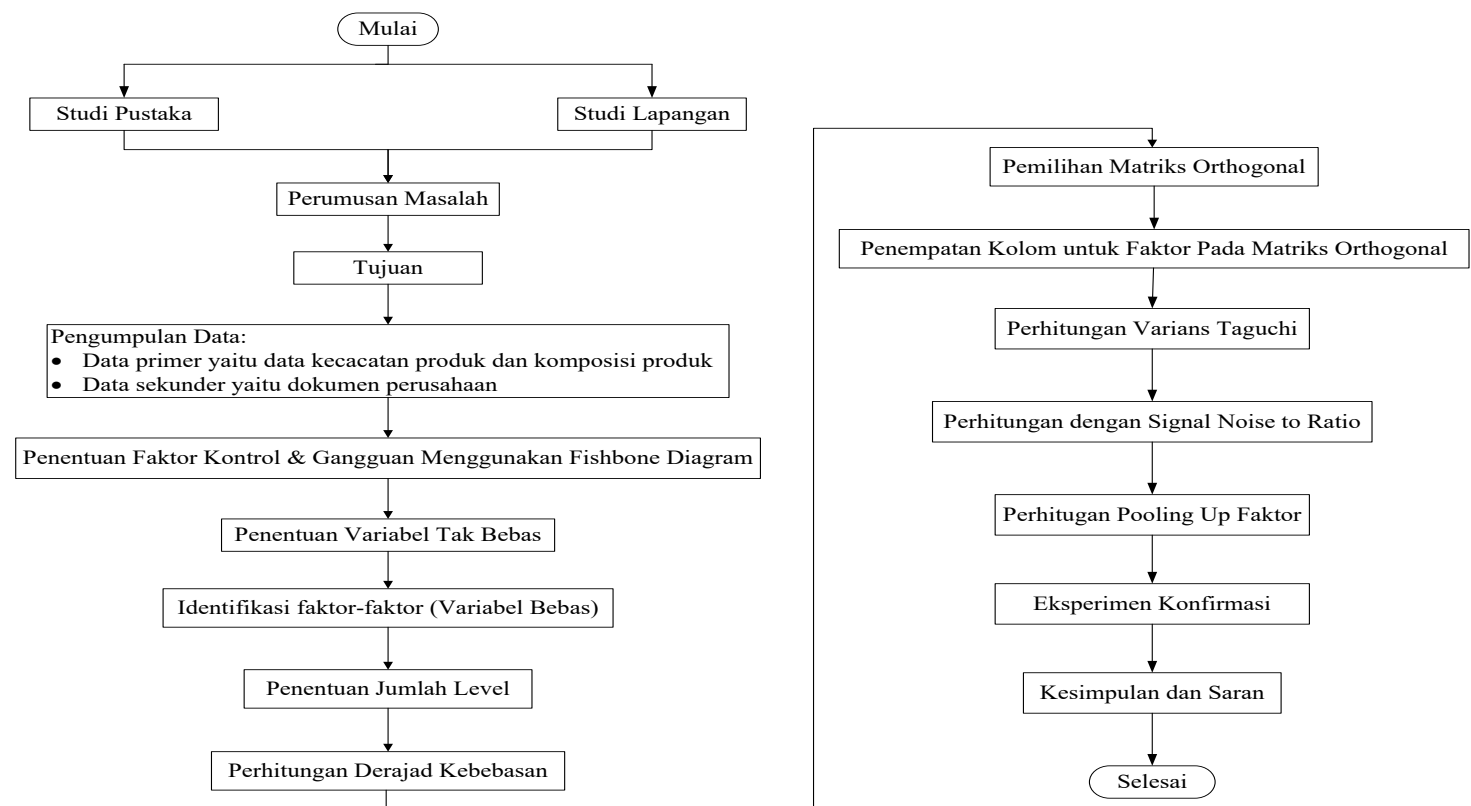

Gambar 1 Flowchart Metode Penelitian

Tahap pertama evaluasi supplier dengan metode Taguchi adalah identifikasi masalah. Tahapan ini dilakukan dengan observasi di Home Industry Putih Jaya, melihat sumber-sumber dari penelitian terdahulu, merumuskan masalah, tujuan dan manfaat penelitian. Tahap kedua yaitu pengumpulan data yang terdiri dari data primer dan sekunder. Data primer didapatkan langsung dari wawancara dan kuisioner sedangkan data sekunder seperti penyimpangan bahan baku didapatkan dari catatan perusahaan mengenai hasil produk cacat selama bulan Juni 2015. Tahap ketiga yaitu tahap pengolahan data yang terdiri dari 10 langkah. Yaitu identifikasi faktor menggunakan 
fishbone diagram dan dilanjutkan menggunakan metode Taguchi. Sehingga menghasilkan komposisi bahan baku optimal yang akan menurunkan tingkat kecacatan. Tahap ke-empat adalah kesimpulan dan saran, tahap ini menjawab dari tujuan penelitian dan memberikan saran bagi peneliti selanjutnya dan bagi perusahaan.

\subsection{Diagram Sebab-akibat}

Diagram sebab-akibat dikembangkan oleh Dr. Kaoru Ishikawa pada tahun 1943, sehingga sering disebut dengan diagram Ishikawa. Diagram ini menggambarkan sebabakibat menggambarkan garis dan simbol-simbol yang menunjukkan hubungan antara akibat dan penyebab suatu masalah[1]. Diagram tersebut digunakan untuk mengetahui akibat dari suatu masalah, sehingga dapat diambil tindakan perbaikan[2]. Dari akibat tersebut, akan dicari beberapa kemungkinan penyebabnya [3].

Manfaat diagram sebab-akibat antara lain adalah :

1. Dapat menggunakan kondisi yang sesungguhnya untuk tujuan perbaikan kualitas produk atau jasa, lebih efisien dalam penggunaan sumber daya, dan dapat mengurangi biaya.

2. Dapat mengurangi dan menghilangkan kondisi yang menyebabkan ketidaksesuaian produk atau jasa dan keluhan pelanggan.

3. Dapat membuat sesuatu standardisasi operasi yang ada maupun yang direncanakan.

4. Dapat memberikan pendidikan dan pelatihan bagi karyawan dalam kegiatan pembuatan keputusan dan melakukan tindakan perbaikan.

\subsection{Metode Taguchi}

Taguchi, G. 1949, mencetuskan metode Taguchi yang bertujuan untuk memperbaiki kualitas produk dan proses. Bukan hanya itu, metode tersebut juga bertujuan untuk menekan biaya dan resources seminimal mungkin[4]. Metode Taguchi menggunakan matriks khusus yang disebut Matriks Ortogonal atau Orthogonanl Array (OA). Matriks standar ini merupakan langkah untuk menentukan jumlah eksperimen minimal. Bagian terpenting dari Matriks Ortogonal terletak pada pemilihan kombinasi level variabel-variabel input masing-masing eksperimen[5].

Karakteristik kualitas adalah hasil suatu proses yang berkaitan dengan kualitas produk yang mellui proses tersebut. Menurut Taguchi [6], karakteristik kualitas yang terukur dapat dibagi menjadi tiga kategori :

1. Nominal is the best

Karakteristik kualitas yang menuju suatu nilai target yang tepat pada suatu nilai tertentu.

2. Smaller the better

Pencapaian karakteristik apabila semakin kecil (mendekati nol; nol adalah nilai ideal dalam hal ini) semakin baik.

3. Larger the better

Pencapaian karakteristik kualitas semakin besar semakin baik (tak terhingga sebagai ilia idealnya)

\subsection{Langkah-langkah pelaksanaan percobaan Taguchi}

Menurut Soejanto [7], tahap terpenting perencanaan percobaan meliputi :

1. Merumuskan / mendefinisikan masalah yang akan diselidiki dalam eksperimen.

2. Tujuan yang melandasi eksperimen harus dapat menjawab apa yang telah dinyatakan pada perumusan masalah, yaitu mencari sebab yang menjadi akibat pada masalah yang kita amati. Pencarian ini lakukan secara sistematis. 
3. Penentuan Variabel tak bebas, yang perubahannya tergantung pada variabelvariabel lain.

4. Identifikasi Faktor-faktor (Variabel Bebas) menggunakan diagram sebab-akibat.

5. Pemisahan Faktor Kontrol dan Faktor Gangguan

6. Penentuan Jumlah Level dan Nilai Level Faktor, hal tersebut penting artinya untuk ketelitian hasil eksperimen dan ongkos pelaksanaan eksperimen.

7. Perhitungan Derajat Kebebasan

Dof untuk faktor $\mathrm{A}=\mathrm{n}_{\mathrm{A}}-1$

Dof untuk interaksi faktor $A$ dan $B=\left(n_{A}-1\right) .\left(n_{B}-1\right)$

Jumlah total Dof $=\left(n_{A}-1\right) \cdot\left(n_{B}-1\right)+\left(n_{A}-1\right) \cdot\left(n_{B}-1\right)$

8. Pemilihan matriks orthogonal yang sesuai, tergantung dari nilai faktor dan interaksi yang diharapkan dan nilai level dari tiap-tiap faktor.

9. Penempatan Kolom untuk Faktor dan Interaksi ke dalam Matriks Ortogonal

10. Persiapan dan Pelaksanaan Percobaan

Pelaksanaan eksperimen meliputi penentuan jumlah replikasi eksperimen dan randomisasi pelaksanaan eksperimen.

a. Jumlah Replikasi dilakukan denga tujuan :

- Menambah ketelitian data eksperimen

- Mengurangi tingkat kesalahan pada eksperimen

- Memperoleh harga taksiran kesalahan eksperimen sehingga memungkinkan diadakannya uji signifikan hasil eksperimen.

b. Randomisasi

11. Analisis Variansi Taguchi

Untuk analisis varians dua arah adalah data eksperimen yang terdiri dari dua faktor atau lebih dan dua level atau lebih.

$\mathrm{S}_{\mathrm{T}}-$ Jumlah Kuadrat Total.

$$
\mathrm{SS}_{\mathrm{T}}=\sum_{i=1}^{n} y^{2}
$$

$\mathrm{S}_{\mathrm{A}}-$ Jumlah Kuadrat Faktor A

$$
\mathrm{SS}_{\mathrm{A}}=\left[\sum_{i=1}^{K A} \frac{A_{i}^{2}}{n_{A i}}-\frac{T^{2}}{n}\right.
$$

$\mathrm{S}_{\mathrm{AxB}}-$ jumlah interaksi $\mathrm{AxB}$

$$
\mathrm{S}_{\mathrm{AxB}}=\frac{(\text { Total } A x B 1)^{2}}{n_{1}}+\frac{(\text { Total } A x B)^{2}}{n_{2}}-\frac{(\text { Total } A x B)^{2}}{n_{1}+n_{2}}
$$

$\mathrm{SS}_{\mathrm{e}}-$ Jumlah Kuadrat error.

$$
\begin{aligned}
& \mathrm{SS}_{\mathrm{T}}=\mathrm{SS}_{\mathrm{A}}+\mathrm{SS}_{\mathrm{B}}+\mathrm{SS}_{\mathrm{AxB}}+\mathrm{SS}_{\mathrm{e}} \\
& \mathrm{SS}_{\mathrm{e}}=\mathrm{SS}_{\mathrm{T}}-\mathrm{SS}_{\mathrm{A}}-\mathrm{SS}_{\mathrm{B}}-\mathrm{SS}_{\mathrm{AxB}}
\end{aligned}
$$

Hasil analisis varians tidak membuktikan adanya perbedaan perlakuan dan pengaruh faktor dalam percobaan, pembuktian ini dilakukan uji hipotesa $\mathrm{F}$.

$$
\mathrm{F}_{\text {sumber }}=\frac{\text { variansi karena perlakuan }+ \text { variansi error }}{\text { variansi karena error }}
$$

Strategi pooling up dirancang Taguchi untuk mengestimasi variansi error pada analisis varians. Rasio $\mathrm{S} / \mathrm{N}$

Rasio S/N (rasio Signal to Noise) digunakan untuk memilih faktor-faktor yang memiliki kontribusi pada pengurangan variasi suatu respon. Rasio S/N yang digunakan yaitu dengan karakteristik kualitas semakin kecil, semakin baik

$$
\mathrm{S} / \mathrm{N}=-10 \log \left(\frac{1}{n} \sum_{i=1}^{r} Y_{i}^{2}\right)
$$




\section{Hasil dan Pembahasan}

Sebelum menentukan matriks orthogonal yang akan digunakan, terlebih dahulu menentukan faktor-faktor kontrol[8]. Faktor-faktor kontrol dilakukan dengan menggunakan diagram sebab akibat, seperti yang ditunjukan pada gambar berikut:

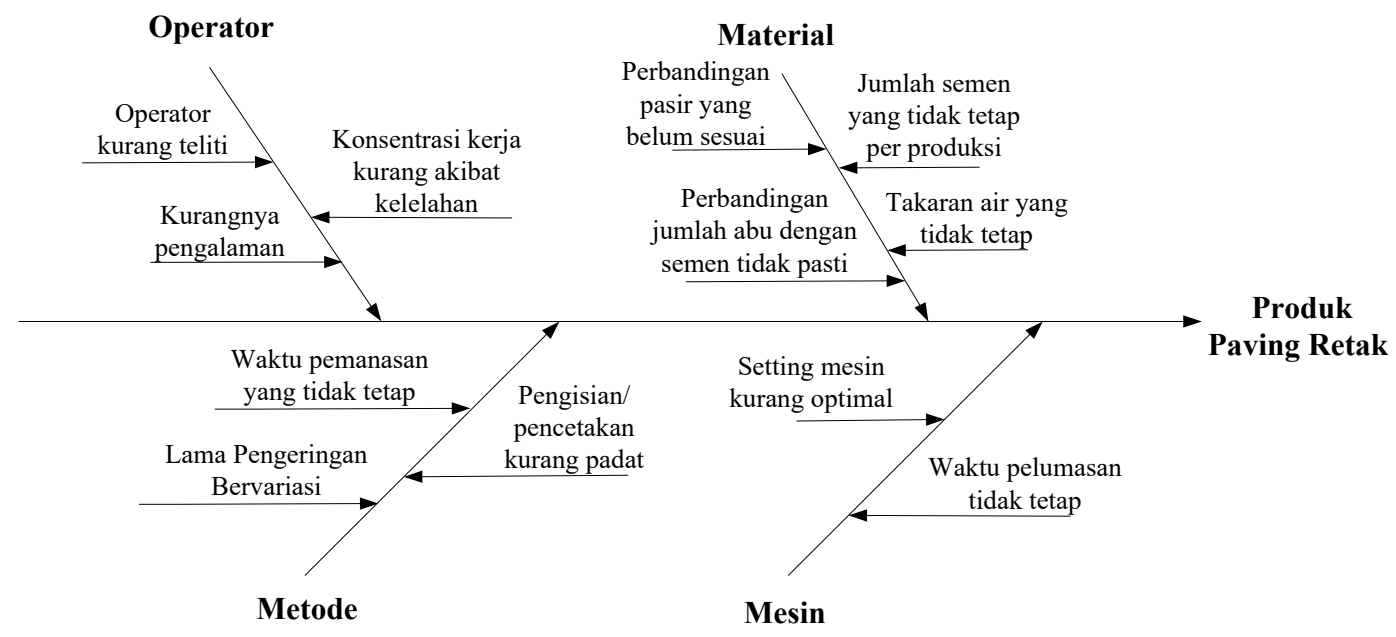

Gambar 2 Diagram Sebab-akibat

Adapun faktor-faktor kontrol yang ditetapkan antara lain : jumlah semen (A), jumlah air (B), jumlah pasir (C), jumlah abu (D), Lama pemanasan (E) dan lama pengeringan (F). Level faktor yang didigunakan adalah 2 level dengan 2 kali replikasi.

\begin{tabular}{|c|c|c|c|}
\hline Faktor & Level 1 & Level 2 & Satuan \\
\hline Semen (A) & 40 & 60 & $\mathrm{~kg}$ \\
\hline Air (B) & 100 & 200 & Liter \\
\hline Pasir (C) & 480 & 420 & $\mathrm{~kg}$ \\
\hline $\mathrm{Abu}(\mathrm{D})$ & 10 & 20 & $\mathrm{~kg}$ \\
\hline Pemanasan (E) & 4 & 10 & Jam \\
\hline Pengeringan (F) & 2 & 4 & Hari \\
\hline
\end{tabular}

Orthogonal array yang dipilih yaitu $\mathrm{L}_{8}\left(2^{7}\right)$, dengan bentuk matriks seperti pada tabel 2. Tabel 3 menunjukkan dalam pencatatan ada dua replikasi yang sama dalam suatu percobaan dengan kondisi yang sama untuk memperoleh ketelitian yang lebih tinggi pada kualitas paving. Hasil percobaan diperoleh dengan cara melakukan percobaan atau setting mesin yang berhubungan dengan kelima faktor yang sebelumnya dibuat sesuai dengan matriks kombinasi level factor. Hal tersebut dilakukan untuk memperoleh nilai taksiran yang lebih akurat mengenai efek dari suatu faktor maka dilakukan pengulangan (replikasi).

Tabel 4 menunjukkan peringkat faktor masing-masing level, setelah dihitung selisih SNR dari kedua level untuk menentukan ranking dari setiap faktor. Faktor yang memiliki selisih terbesar dibuat ranking satu demikian seterusnya. Ranking tersebut menyatakan seberapa besar pengaruh atau kontribusinya terhadap kualitas produk Berdasarkan hasil perhitungan Signal to Noise Ratio (SNR) dapat diperoleh bahwa faktor A level 1 memiliki pengaruh atau kontribusi yang besar terehadap hasil eksperimen dengan nilai SNR sebesar -16,739 dan yang kurang berpengaruh adalah faktor F level 1 dengan nilai SNR sebesar -14,5825. 
Tabel 2 Matriks Orthogonal Array

\begin{tabular}{cccccccc}
\hline \multirow{2}{*}{ Eksperimen } & \multicolumn{7}{c}{ Kolom/Faktor } \\
\cline { 2 - 8 } & A & B & C & D & E & F & G \\
\hline 1 & 1 & 1 & 1 & 1 & 1 & 1 & 1 \\
2 & 1 & 1 & 1 & 2 & 2 & 2 & 2 \\
3 & 1 & 2 & 2 & 1 & 1 & 2 & 2 \\
4 & 1 & 2 & 2 & 2 & 2 & 1 & 1 \\
5 & 2 & 1 & 2 & 1 & 2 & 1 & 2 \\
6 & 2 & 1 & 2 & 2 & 1 & 2 & 1 \\
7 & 2 & 2 & 1 & 1 & 2 & 2 & 1 \\
8 & 2 & 2 & 1 & 2 & 1 & 1 & 2 \\
\hline
\end{tabular}

Tabel 3 Hasil Percobaan Terhadap Kecacatan Produk Paving

\begin{tabular}{ccccccccccc}
\hline \multirow{2}{*}{ Eksperimen } & \multicolumn{1}{c}{ Faktor } & Rep 1 & Rep 2 & $\begin{array}{c}\text { Rata- } \\
\text { rata }\end{array}$ \\
\cline { 2 - 7 } & A & B & C & D & E & F & e & & & 6 \\
2 & 1 & 1 & 1 & 1 & 1 & 1 & 1 & 7 & 5 & 6.5 \\
3 & 1 & 1 & 1 & 2 & 2 & 2 & 2 & 10 & 5 & 9 \\
4 & 1 & 2 & 2 & 1 & 1 & 2 & 2 & 8 & 10 & 9 \\
5 & 1 & 2 & 2 & 2 & 2 & 1 & 1 & 6 & 5 & 5.5 \\
6 & 2 & 1 & 2 & 1 & 2 & 1 & 2 & 6 & 4 & 5 \\
7 & 2 & 1 & 2 & 2 & 1 & 2 & 1 & 7 & 6 & 6.5 \\
8 & 2 & 2 & 1 & 1 & 2 & 2 & 1 & 5 & 7 & 6 \\
\hline
\end{tabular}

Tabel 4 Peringkat Faktor Berdasarkan S/N Ratio

\begin{tabular}{ccccccc}
\hline & A & B & C & D & E & F \\
\hline Level 1 & -16.739 & -15.825 & -15.652 & -16.048 & -16.221 & -14.582 \\
Level 2 & -14.945 & -15.859 & -16.032 & -15.637 & -15.463 & -17.102 \\
Selisih & 1.794 & 0.033 & 0.381 & 0.411 & 0.759 & 2.520 \\
Rank & 2 & 7 & 6 & 5 & 3 & 1 \\
\hline
\end{tabular}

Tabel 5 Analisa Varians

\begin{tabular}{cccc}
\hline Sumber & Dof & SS & MS \\
\hline A & 1 & 3,78 & 3,78 \\
B & 1 & 0,0312 & 0,0312 \\
C & 1 & 0,2812 & 0,2812 \\
D & 1 & 0,2812 & 0,2812 \\
E & 1 & 0,7812 & 0,7812 \\
F & 1 & 7,03 & 7,03 \\
Error & $\mathbf{5}$ & $\mathbf{0 , 7 8 1 6}$ & $\mathbf{0 , 1 5 7}$ \\
Total & $\mathbf{8}$ & $\mathbf{1 2 , 9 7}$ & \\
\hline
\end{tabular}


Analisis varians perhitungan jumlah kuadrat error digunakan untuk mengetahui error yang terjadi yang diperolah dari selisih jumlah kuadrat total dengan seluruh kuadrat rata-rata dan jumlah kuadrat level faktor[9]. Hasil dari perhitungan tersebut diperoleh error sebesar 0,7816 yang digunakan untuk menghitung error pada analisa varians. Dengan error 0,7816 dan derajat kebebasan 6 diperoleh error kuadrat rata-rata (mean square) sebesar 0,157.

Tabel 6 Analisa Varians Penggabungan

\begin{tabular}{cccc}
\hline Sumber & Dof & SS & MS \\
\hline A & 1 & 3,78 & 3,78 \\
B & Pooling terhadap faktor B \\
C & 1 & 0,2812 & 0,2812 \\
D & 1 & 0,2812 & 0,2812 \\
E & 1 & 0,7812 & 0,7812 \\
F & 1 & 7,03 & 7,03 \\
Error & $\mathbf{7}$ & $\mathbf{0 , 8 1 6 4}$ & $\mathbf{0 , 1 3 6}$ \\
Total & $\mathbf{8}$ & $\mathbf{1 2 , 9 7}$ & \\
\hline
\end{tabular}

Tabel 7 Hasil Analisa Varians Penggabungan

\begin{tabular}{|c|c|c|c|c|}
\hline Sumber & Dof & SS & MS & F - Ratio \\
\hline A & 1 & 3,78 & 3,78 & 27,79 \\
\hline B & \multicolumn{4}{|c|}{ Pooling terhadap faktor B } \\
\hline C & 1 & 0,2812 & 0,2812 & 2,06 \\
\hline $\mathbf{D}$ & 1 & 0,2812 & 0,2812 & 2,06 \\
\hline $\mathbf{E}$ & 1 & 0,7812 & 0,7812 & 5,74 \\
\hline $\mathbf{F}$ & 1 & 7,03 & 7,03 & 51,7 \\
\hline Error & 7 & 0,8164 & 0,136 & - \\
\hline Total & 8 & 20 & - & - \\
\hline
\end{tabular}

Tabel 6 dan 7 menunjukkan Pooling up yang dilakukan untuk mengumpulkan faktor-faktor yang tidak signifikan yang disebut sebagai error. Faktor dikatakan tidak signifikan apabila $\mathrm{MS}_{\text {hitung }} \leq \mathrm{MS}_{\text {error}}$, Tabel 4.7 menunjukkan bahwa faktor B tidak signifikan dan dianggap sebagai error karena $\mathrm{MS}_{\text {hitung faktor B lebih kecil dibandingkan }}$ dengan $\mathrm{MS}_{\text {error }}$ sehingga faktor B di-pooling up. Dengan mem-pooling faktor B maka diperoleh $\mathrm{MS}_{\text {eror }}$ sebesar 0,136 yang sebelumnya 0,157 yang artinya terjadi penurunan nilai error.

Pengujian hipotesa dan kesimpulan dengan tingkat kepercayaan 90\% yang diperoleh dari tabel analisa varians setelah dilakukan poolin up terhadap faktor B adalah Ho faktor $\mathrm{F}$ diterima yang artinya faktor $\mathrm{F}$ memiliki pengaruh yang sangat besar dengan nilai 51,7 .

Analisis perhitungan persen kontribusi digunakan untuk mengetahui seberapa besar persen kontribusi dari masing-masing faktor terhadap kualitas produk paving[10]. Perhitungan persen kontribusi diperoleh dari perbandingan nilai $\mathbf{S S}_{\text {faktor }}$ terhadap SS $_{\text {Total }}$. Dari hasil perhitungan persen kontribusi diperoleh bahwa faktor F (lama pengeringan) memiliki kontribusi terbesar yaitu $34,5 \%$. 
Tabel 8 Persen Kontribusi

\begin{tabular}{ccccccc}
\hline Sumber & Dof & SS & MS & F - Ratio & SS & P (\%) \\
\hline A & 1 & 3,78 & 3,78 & 27,79 & 3,644 & 18,22 \\
C & 1 & 0,2812 & 0,2812 & 2,06 & 0,1452 & 0,73 \\
D & 1 & 0,2812 & 0,2812 & 2,06 & 0,1452 & 0,73 \\
E & 1 & 0,7812 & 0,7812 & 5,74 & 0,6452 & 3,2 \\
F & 1 & 7,03 & 7,03 & 51,7 & 6,894 & 34,5 \\
Error & $\mathbf{7}$ & $\mathbf{0 , 8 1 6 4}$ & $\mathbf{0 , 1 3 6}$ & - & - & - \\
Total & $\mathbf{8}$ & $\mathbf{2 0}$ & - & - & - & - \\
\hline
\end{tabular}

Berdasarkan pengolahan data di atas diperoleh bahwa faktor yang berpengaruh terhadap kualitas paving adalah jumlah Semen (A). Karakteristik kualitas yang digunakan adalah smaller the better maka pemilihan level faktor berdasarkan nilai level yang terkecil yaitu faktor A level 2. sehingga menghasilkan kombinasi setting optimal A2, B1, C1, D2 dan E2.

Tabel 9 Hasil Kombinasi Terpilih

\begin{tabular}{|c|c|c|c|c|}
\hline \multicolumn{3}{|c|}{ Faktor } & Level & Satuan \\
\hline \multicolumn{3}{|c|}{ Jumlah Semen yang digunakan (A2) } & 60 & $\mathrm{Kg}$ \\
\hline \multicolumn{3}{|c|}{ Jumlah Air yang dibutuhkan (B1) } & 100 & Liter \\
\hline \multicolumn{3}{|c|}{ Jumlah Pasir yang digunakan (C1) } & 480 & $\mathrm{Kg}$ \\
\hline \multicolumn{3}{|c|}{ Jumlah abu yang digunakan (D2) } & 10 & $\mathrm{Kg}$ \\
\hline \multicolumn{3}{|c|}{ Waktu Pemanasan (E2) } & 10 & Jam \\
\hline \multicolumn{3}{|c|}{ Lama Pengeringan (F1) } & 4 & Hari \\
\hline \multicolumn{5}{|c|}{ Tabel 10 Hasil Percobaan Konfirmasi } \\
\hline Eksperimen & $\begin{array}{l}\text { Jumlah } \\
\text { Paving }\end{array}$ & $\operatorname{Rep} 1$ & $\operatorname{Rep} 2$ & $\begin{array}{c}\text { Rata- } \\
\text { rata }\end{array}$ \\
\hline 1 & 170 & 4 & 1 & 2.5 \\
\hline 2 & 170 & 3 & 1 & 2 \\
\hline 3 & 170 & 2 & 0 & 1 \\
\hline 4 & 170 & 2 & 0 & 1 \\
\hline 5 & 170 & 0 & 0 & 0 \\
\hline 6 & 170 & 1 & 3 & 2 \\
\hline 7 & 170 & 0 & 2 & 1 \\
\hline 8 & 170 & 1 & 2 & 1.5 \\
\hline \multicolumn{3}{|c|}{ Jumlah } & & 11 \\
\hline \multicolumn{3}{|c|}{ Rata-rata } & & 1.375 \\
\hline
\end{tabular}

Dari tabel 10, penilaian diterima atau tidaknya hasil eksperimen konfirmasi dilakukan dengan perbandingan selang kepercayaan antara hasil prediksi respon pada kondisi optimal dan hasil eksperimen konfirmasi. Selang kepercayaan prediksi optimal diperoleh sebesar 0,34 sehingga interval kepercayaan prediksi optimal yaitu 3,58 $\leq 3,92$ $\leq 4,26$. Selang kepercayan konfirmasi diperoleh sebesar 0,129 sehingga intervalnya berada diantara $01,246 \leq \boldsymbol{\mu}$ prediksi $\leq 1,504$. 


\section{Simpulan}

Setelah melakukan penelitian dan percobaan yang dilakukan di Home Industri Putih Jaya terhadap kualitas produk paving maka dapat dia mbil beberapa kesimpulan. Faktor-faktor yang berpengaruh secara signifikan terhadap kualitas produk paving antara lain adalah : jumlah semen sebagai bahan baku dalam pencampuran dengan persen kontribusi sebesar 18,22\%, jumlah pasir sebagai bahan baku dengan persen kontribusi sebesar 0,73 , jumlah abu sebagai bahan tambahan dalam pencampuran dengan persen kontribusi sebesar 0,73\%, lama pemanasan yang dilakukan setelah proses pencetakan dengan persen kontribusi sebesar 3,2\% dan lama waktu proses pengeringan yang dilakukan setelah proses pemanasan dengan persen kontribusi sebesar 34,5\%. Kombinasi setting yang optimal untuk mengurangi jumlah kecacatan yang disebabkan oleh faktor proses dan bahan baku adalah A2 (jumlah semen yang digunakan sebesar 60kg), B1 (jumlah air yang dibutuhkan 100liter), C1 (jumlah pasir yang digunakan sebesar 480kg), D2 (jumlah abu yang digunakan sebagai bahan baku tambahan sebesar 10kg), E2 (lama waktu pemanasan selama 16 hari) dan F1 (lama waktu pengeringan selama 4 hari). Sehingga pada proses memproduksi paving mengalami penurunan tingkat kecacatan hingga $3 \%$ per harinya.

\section{Referensi}

[1] R. S. Kenett, "Cause-and-Effect Diagrams," Wiley StatsRef: Statistics Reference Online, 2014.

[2] S.-Y. Tseng, S.-w. Tseng, and B.-s. Lin, "How To Improve The Haccp System In An International Tourist Hotel Group? Cause-And-Effect Analysis And Pdca Application," International Journal of Tourism \& Hospitality Reviews, vol. 3, pp. 60-68, 2016.

[3] D. C. Montgomery, Introduction to statistical quality control: John Wiley \& Sons, 2007.

[4] B. Gunawan, "Metode Taguchi Sebagai Salah Satu Alternatif Pengendalian Biaya Mutu," Jurnal Akuntansi dan Investasi, vol. 2, pp. 45-55, 2015.

[5] Ş. Karabulut, "Optimization of surface roughness and cutting force during AA7039/Al2O3 metal matrix composites milling using neural networks and Taguchi method," Measurement, vol. 66, pp. 139-149, 2015.

[6] G. S. Peace, Taguchi methods: a hands-on approach: Addison Wesley Publishing Company, 1993.

[7] I. Soejanto, Desain Eksperimen dengan Metode Taguchi. Yogyakarta: Graha Ilmu, 2009.

[8] J. Pang, M. Ansari, O. S. Zaroog, M. H. Ali, and S. Sapuan, "Taguchi design optimization of machining parameters on the CNC end milling process of halloysite nanotube with aluminium reinforced epoxy matrix (HNT/Al/Ep) hybrid composite," HBRC Journal, vol. 10, pp. 138-144, 2014.

[9] K. Pawar and R. Palhade, "Multi-objective Optimization of CNC Turning Process Parameters for High Speed Steel (M2) Using Taguchi and ANOVA Method," International Journal of Hybrid Information Technology, vol. 8, pp. 67-80, 2015.

[10] Y. T. Chung, M. M. Ba-Abbad, A. W. Mohammad, N. H. H. Hairom, and A. Benamor, "Synthesis of minimal-size $\mathrm{ZnO}$ nanoparticles through sol-gel method: Taguchi design optimisation," Materials \& Design, vol. 87, pp. 780-787, 2015. 